\title{
Study of Role of Iron Deficiency Anaemia in Febrile Seizures in Children in a Tertiary Care Centre
}

\author{
Sreenivasa $\mathrm{B}^{1}$, Kumar $\mathrm{GV}^{2}$, Manjunatha $\mathrm{B}^{3}$
}

\begin{abstract}
Introduction: The world health organization estimates that anaemia largely caused by iron deficiency, affecting between 500 million and two billion people worldwide. Considering the age prevalence of iron deficiency anaemia and febrile convulsion which are the same, the role of iron in the metabolism of neurotransmitter and some enzymes, the function of hemoglobin in conveying oxygen to the brain and since fever can exacerbate symptoms that result from anaemia, a relationship between iron deficiency anaemia and febrile convulsions is probable. Some studies have suggested iron deficiency as a predisposing factor for febrile seizures. We designed this case control study to evaluate the relationship between iron deficiency anaemia and febrile convulsions. The objective of this study was to study the role of iron deficiency as a risk factor for febrile seizures. Materials and Methods: Hundred cases and 100 controls were included in the study. Cases were children of age group six months to six years presenting with febrile seizures. Controls were children of same age group presenting with febrile illness but without any seizures. After informed consent, detailed history was taken and clinical examination done in both cases and controls and blood investigations were done to diagnose iron deficiency anemia. Two groups were matched for age and sex .In all children hemoglobin ( $\mathrm{Hb})$ level, mean corpuscular volume (MCV), mean corpuscular hemoglobin $(\mathrm{MCH})$, red cell distribution width (RDW) and plasma ferritin (PF) were determined and the data collected were analyzed statistically. Results: The mean PF was significantly lower in cases compared to controls $(p=0.000)$ and RDW was significantly higher in cases compared to controls $(p=0.00)$.The mean $\mathrm{Hb} \%, \mathrm{MCV}, \mathrm{MCH}$ are lower in cases compared to controls but it was statistically not significant. Concluson: Iron deficiency is a significant risk factor for febrile seizures in children of age group six months to six years. Early detection and timely correction of iron deficiency may be helpful for prevention of febrile seizures in children
\end{abstract}

Key words: Febrile seizures, iron deficiency anemia, serum ferritin

\section{Introduction}

The world health organization estimates that anaemia largely caused by iron deficiency, affecting between 500 million and
'Dr. Bheema Naik Sreenivasa, MBBS. MD, Associate Professor, Department of Paediatrics, Basaweshwara Medical College, Chithradurga, Karnataka, India. ${ }^{2}$ Dr. Gowripura Visweswaraiah Kumar, MBBS.DCH. DNB, Associate Professor, Department of of Paediatrics, Sri Siddhartha Medical College, Tumkur, Karnataka, India. ${ }^{3}$ Dr. Bheema Naik Manjunatha, MBBS. DCH, Senior Resident of Paediatrics, Basaweshwara Medical College, Chithradurga, Karnataka, India.

\author{
Address for correspondence: \\ Dr. Kumar GV \\ Associate Professor, Department of Paediatrics \\ Sri Siddhartha Medical College, \\ Tumkur, Karnataka, India. PIN 572107 \\ E-mail: kumargowripura@yahoo.co.in \\ Tel: +919739306525
}

\section{How to cite}

Sreenivasa B, Kumar GV, Manjunatha B. Study of Role of Iron Deficiency Anaemia in Febrile Seizures in Children in a Tertiary Care Centre. J Nepal Paediatr Soc 2015;35(2):148-151.

doi: http://dx.doi.org/10.3126/jnps.v35i2.12845

This work is licensed under a Creative Commons Attribution 3.0 License.

\section{(c) (7)}

two billion people world wide ${ }^{1,2}$. It is the most common nutritional deficiency and haematological disease of infancy and childhood $^{3}$. Iron is a nutritional element not only needed for the synthesis of haemoglobin, but it is also essential for enzymes involved in neurochemical reactions ${ }^{4}$. To date, the pathophysiology 
of febrile seizure is unknown ${ }^{5}$. Age for peak incidence of febrile seizure is 14 to 18 months, which overlaps with that of iron deficiency anaemia which is form 6 to 24 months ${ }^{6,7}$. Considering the age prevalence of iron deficiency anaemia and febrile convulsion which are the same, the role of iron in the metabolism of neurotransmitter (such as GABA and serotonin) and some enzymes (such as monoaminoxidase and aldehidoxidase), the function of hemoglobin in conveying oxygen to the brain and since fever can exacerbate symptoms that result from anaemia, a relationship between iron deficiency anaemia and febrile convulsions is probable $8,9,10$.

Some studies have suggested iron deficiency as a predisposing factor for febrile seizures, some described iron deficiency anaemia is less frequent in children with febrile seizures ${ }^{11}$. Considering the conflicting results of the previous studies, we designed this case control study to evaluate the relationship between iron deficiency anaemia and febrile convulsions.

\section{Material and Methods}

A case control study was conducted from July 2010 to October 2014 in Basaveshwara Medical college hospital Chitradurga. One hundred children aged between 6 months to 6 years with febrile seizures were enrolled as cases. Sample size was based on $Z$ formula and confidence interval of $95 \%$ with $80 \%$ power, type one error of $5 \%$ to detect any significant difference between the two groups with a level of 0.05 . Febrile seizures were defined as a seizure occurring in association with a febrile illness, in the absence of CNS infection or any other defined causes of seizures ${ }^{12}$. Children with a history of seizures, thalassaemia, central nervous system (CNS) infections, developmental delay and neurological deficits, on iron therapy were excluded from the study. A control group of 100 children was selected from among children hospitalized for a febrile illness (such as upper and lower respiratory tract infections and gastroenteritis) but without seizures. Controls were group matched to cases on age and sex. An informed consent was obtained from parents or the guardian. Demographic data, seizure details, nature of febrile illness, the family history of epilepsy/febrile seizures, temperature at admission, and nutritional status were recorded. Blood samples were collected from all participants for measurement of haemoglobin $(\mathrm{Hb})$, mean corpuscular volume (MCV), mean corpuscular haemoglobin $(\mathrm{MCH})$, red cell distribution width (RDW) and serum ferritin was done. Ethical committee clearance was sorted out.
Iron deficiency anaemia was defined as $\mathrm{Hb}$ $<11 \mathrm{~g} / \mathrm{dl}, \mathrm{MCV}<70 \mathrm{fl}, \mathrm{MCH}<27 \mathrm{pg}, \mathrm{RDW}>15 \%$, serum ferritin $<12 \mathrm{ng} / \mathrm{ml}(\mathrm{WHO})^{13}$. In presence of fever, a higher cut-off value of serum ferritin $(25-50 \mathrm{ng} / \mathrm{ml})$ was considered ${ }^{14}$. Cases and controls were compared with respect to blood indiciesand serum ferritin. Chisquare and ANOVA tests for discontinuous variable and unpaired t-test for continuous variable at $5 \%$ significance $(p<0.05)$ level were used for statistical analysis.

\section{Results}

100 cases ( 56 male, 44 female) and 100 controls (52 male, 48 female) were enrolled. The mean ages of patients in the febrile seizure and control groups were $1.5 \pm 1.2$ and $1.9 \pm 1.5$ year respectively.

Table 1: Peak temperature on admission, underlying causes of fever among cases and controls

\begin{tabular}{|l|c|c|c|}
\hline Characteristic & $\begin{array}{c}\text { Febrile seizure } \\
\text { cases }(\mathbf{n = 1 0 0 )}\end{array}$ & $\begin{array}{c}\text { Controls } \\
(\mathbf{n}=100)\end{array}$ & $\boldsymbol{p}$-value \\
\hline $\begin{array}{l}\text { Temperature } \\
\text { peak at } \\
\text { admission in c } \\
\text { (mean) }\end{array}$ & 39 & 38.8 & $\begin{array}{c}0.61 \\
\text { (N.S) }\end{array}$ \\
\hline $\begin{array}{l}\text { Respiratory } \\
\text { tract infections }\end{array}$ & 60 & 59 & N.S \\
\hline Gastroenteritis & 15 & 14 & N.S \\
\hline Dengue fever & 10 & 10 & N.S \\
\hline Enteric fever & 10 & 9 & N.S \\
\hline Viral fever & 5 & 8 & N.S \\
\hline
\end{tabular}

N.S = Not significant statistically

Respiratory tract infections were the most common cause of fever in our study followed by gastroenteritis.

Table 2: Haematological parameters of cases and controls

\begin{tabular}{|c|c|c|c|}
\hline Parameters & $\begin{array}{c}\text { Cases } \\
\mathbf{n = 1 0 0} \\
\text { (Mean } \pm \text { SD })\end{array}$ & $\begin{array}{c}\text { Controls } \\
\mathbf{n = 1 0 0} \\
\text { (Mean } \pm \text { SD ) }\end{array}$ & $p$-value \\
\hline $\mathrm{Hb} \%$ & $9.4 \pm 1.2$ & $9.5 \pm 1.0$ & 0.70 \\
\hline $\mathrm{MCV}$ (fl) & $73.3 \pm 5.1$ & $74.0 \pm 4.9$ & 0.36 \\
\hline $\mathrm{MCH}$ (pg) & $25.1 \pm 3.6$ & $25.7 \pm 3.1$ & 0.26 \\
\hline $\mathrm{RDW} \%$ & $16.8 \pm 1.3$ & $12.7 \pm 1.1$ & 0.00 \\
\hline $\begin{array}{c}\text { Serum ferritin } \\
\text { (ng/ml) }\end{array}$ & $29.5 \pm 21.3$ & $53.3 \pm 37.6$ & 0.000 \\
\hline
\end{tabular}

In this study we observed significantly low serum ferritin and significantly higher RDW in febrile seizure cases compared to controls 


\section{Discussion}

Numerous studies have addressed the association between iron deficiency anemia and febrile seizure in children. The results, however, have been controversial and even primary researches with high number of cases have failed to provide unequivocal results. We observed significantly low serum ferritin levels in children with febrile seizures than in controls. Similar results were observed by Pisacame, etal ${ }^{15}$. But in contrast with these studies Mansourietal reported mean ferritin was higher in the convulsive group with no statistically significant difference ${ }^{16}$. Kobrinsky et al deduced that iron deficiency might have a protective effect on febrile convulsion ${ }^{17}$.

Iron has been found to act as a cofactor in a number of enzymatic reactions at the cellular level and effects neurotransmitter production and function, hormone function and DNA replication. Deficiency of iron, therefore, results in disruption of normal cell and organ function.

Iron deficiency is associated with neurological problems in young children, including developmental delay, stroke, and breath-holding spells. Screening for IDA should be considered in children with febrile seizures. Fever can worsen the negative effect of anaemia or for iron deficiency on the brain and a seizure can occur as a consequence. Alternatively, anaemia can be associated with the severity of a febrile illness, and more severe cases could be more likely to get seizures ${ }^{17}$.

Iron deficiency anaemia may reduce the seizure threshold in the infancy and childhood. Low PF level is associated with and may play a role in febrile seizures. ${ }^{17}$

The study has some limitations. Serum ferritin, a nonspecific acute phase reactant can rise in any inflammatory conditions, although both cases and controls were having fever at the time of enrollment. Iron deficiency and lead poisoning may be associated. Blood lead levels could not be determined in our subjects.

Although serum ferritin levels rise in inflammatory conditions, MCV and RDW are not affected by acute infection $^{18}$. RDW has been shown to distinguish between patients with lead poisoning and iron deficiency in children with microcytic anaemia. Specifically the RDW is elevated in iron deficient patients with lead poisoning and normal in children with lead poisoning alone ${ }^{19}$.

\section{Conclusions}

Iron deficiency anaemia is a modifiable risk factor for febrile seizure in children. Early detection and timely correction of iron deficiency may be helpful for prevention of febrile seizures in children.

Acknowledgements: Nil

Funding: None

Conflict of Interest: Nil

Permission from IRB: Yes

\section{References}

1. Lozoff B, Jimenez E, Smith JB. Double burden of iron deficiency in infancy and low socioeconomic status. Arch Pediatr Adoless Med 2006; 160:110812.

2. Mahoney DH. Iron-Deficiency Anaemia in children. (Web document) www.UptoDate.com. Last Literature Review version 2009;17.2: May

3. Ohls RK, Christensen RD. Iron-Deficiency Anaemia. Nelson Text book of Pediatrics.18th Edition. Philadelphia: Saunders; 2008. p. 2014-7.

4. Ambruso DR, Hays T, Goldenberg NA. Iron Deficiency Anaemia. Current Diagnosis and Treatment- Paediatrics. 19 ${ }^{\text {th }}$ Edition. Denver USA: McGraw Hill; 2009. P.810-11.

5. Varma RR. Febrile seizures. Indian J Pediatr 2002; 69(8):697-700.

6. Johnston VJ. Seizures in Childhood. Nelson Text book of Pediatrics.18th Edition. Philadelphia: Saunders; 2009. P.1994-5.

7. Fishman MA. Febrile seizures. (Web document) www.UptoDate.com Last Literature Review version 2010; 8.1.

8. Harris RJ. Iron deficiency anaemia: does it really matter? Paediatr Child Health 2007; 17(4):143.

9. Parks YA, Wharton BA. Iron deficiency and the brain. ActaPaediatrScand 1989; S5 (suppl 361):71 7.

10. Weatherall DJ, Clegg JB. The thalassaemia syndromes.4th ed. London:Blackwell Science; 2001;P. 192,231.

11. Bidabadi E, Mashouf M. Association between iron deficiency anemia and first febrile convulsion: A case-control study. Seizure 2009; 18(5):347-51.

12. Johnston MV. Seizures in childhood: Febrile seizures. In: Behrman RE, Kliegman RM, Jenson HB, editors. Nelson's Textbook of Pediatrics. 17th ed. Pennsylvania: Saunders; 2004; p. 1994-1995. 
13. World Health Organization. Iron Deficiency Anemia. Assessment, Prevention and Control. A Guide for Program Managers. WHO/NHD/013; Geneva: 2001.

14. Dallman PR, Yip R, Oski FA. Iron deficiency and related nutritional anemias. In: Nathan DG, Oski FA, editors. Hematology of Infancy and Childhood. 4th ed. Mexico: Saunders; 1993; p. 413- 450.

15. Pisacane A, Sansone $R$, Impagliazzo $N$, Coppola A,Rolando P, D'Apuzzo A, et al. Iron deficiencyanemia and febrile convulsion: Case control study in children under 2 years. BMJ 1996; 313:343.

16. Mansouri M, Bidabadi E, Sobhani AR. Relation Of Iron Deficiency Anemia with First Febrile
Convulsion In 6 month to 5 year old Children. J Med Faculty Guilan Univ Med Sci 2007; 60(15):6573.

17. Kobrinsky N, Yager JY, CheangMs, Yatscoff RW, Tenenbein M. Does iron deficiency raise the seizure threshold? J Child Neurol 1995; 10(2):105-9.

18. Kim SK, Cheong WS, Jun YH, et al. Red blood cell indices and iron status according to feeding practices in infants and young children. Acta Paediatr 1996; 85:139-144.

19. Bhambhani K, Aronow R. Lead poisoning and thalassemia trait or iron deficiency: the value of the red blood cell distribution width. Am J Dis Child 1990; 144: 1231-1233. 